\title{
MECHANIZMY KARIER NA DWORACH KOBIECYCH W WERSALU W DRUGIEJ POŁOWIE XVIII WIEKU*
}

\author{
Katarzyna Kuras (D) http://orcid.org/0000-0002-6198-7131 \\ Uniwersytet Jagielloński w Krakowie
}

\author{
ABSTRACT \\ THE CAREER MECHANISMS AT THE WOMEN'S COURTS \\ IN VERSAILLES IN THE SECOND HALF OF THE $18^{\text {TH }}$ CENTURY
}

The purpose of the article is to examine the career mechanisms at the royal court in Versailles mainly in the $60 \mathrm{~s}$ and $70 \mathrm{~s}$ of the $18^{\text {th }}$ century in reference to the households (maisons) of Queen Marie Leszczyńska (d. 1768) and Dauphine Marie Josephe of Saxony (d. 1767). The structures and sustainability of these households went beyond the usual patterns as a result of accidental circumstances and ad hoc decisions taken by King Louis XV. The accumulation of problems and surprising circumstances forced him to take non-stereotypical actions. Reforms - even the smallest ones - revealed additionally the signs of crisis, which was systematically increasing at the entire court in Versailles. As a result, in the second half of the $18^{\text {th }}$ century, the modernization of the court was also a sign of its serious crisis, and the careers of maisons' officials were directed by new mechanisms that had previously not existed.

Keywords: Versailles, French court, Queen Marie Leszczyńska, Dauphine Marie Josephe of Saxony, Queen Marie Antoinette.

Słowa kluczowe: Wersal, dwór francuski, Maria Leszczyńska, Maria Józefa Saska, Maria Antonina.

Wersal był autorskim dziełem króla Ludwika XIV Burbona. Monarcha znacząco powiększył sam pałac, wcześniej będący rezydencją myśliwską ojca, w 1683 roku podjął decyzję o uczynieniu z niego swej stałej siedziby i serca Królestwa Francji, wreszcie stworzył system, który przyciągał tu rzesze francuskiej szlachty spragnionej

\footnotetext{
* Badania nad tematyką artykułu były realizowane w ramach grantu 2014/13/B/HS3/04975 „Dwór królowej Marii Leszczyńskiej. Ludzie, pieniądze i wpływy” finansowanego przez Narodowe Centrum Nauki.
}

Adres do korespondencji: katarzyna.kuras@uj.edu.pl 
łask oraz zaszczytów związanych z przebywaniem u boku władcy ${ }^{1}$. Ludwik XIV odpowiadał również za przyjęcie regulacji, które sprawiały, że życie spędzane w pałacu posiadało sztywne, formalne ramy (znaczna część z nich opierała się na przepisach stworzonych przez poprzedników, zwłaszcza Henryka III Walezjusza). Król Słońce prowadził dość regularny tryb życia, a jego dworzanie, starając się o przyjęcie na służbę, musieli spełniać wiele wymagań oraz zaakceptować różne organizacyjne szczegóły, na przykład pracę w systemie półrocznym, kwartalnym bądź miesięcznym. W zamian otrzymywali status commenseaux, czyli stołowników króla, pewne - nieraz złożone $\mathrm{z}$ wielu elementów - uposażenie, mieszkanie lub rekompensatę finansową w wypadku braku możliwości zakwaterowania w pałacu lub budynkach doń przynależących².

Stabilny wzorzec stworzony w czasach Króla Słońce trwał aż do końca ancien régime'u. Upływ czasu zacierał istotę poszczególnych reguł, czyniąc z nich wyłącznie formalną sztancę, w obrębie której - już bardzo intuicyjnie - poruszano się za Ludwika XV oraz Ludwika XVI. Wiele wskazuje, że żaden z nich nie wierzył ani w sakralny charakter swej władzy, ani w system dworski w znaczeniu, jakie nadał mu jego twórca ${ }^{3}$. Ta ociężała pałacowa machina trwała w dużej mierze na zasadzie siły inercji scementowanej wspomnieniami chwały Króla Słońce i pamięcią o jego panowaniu. W tak funkcjonującym układzie każda poważna zmiana była nie tyle szansą, ile zagrożeniem dla pozbawionego wewnętrznej spoistości systemu.

Celem tego studium jest analiza różnego rodzaju działań podejmowanych głównie w latach 60. i 70. XVIII wieku w obrębie maisons delfiny Marii Józefy oraz królowej Marii Leszczyńskiej, których struktury i trwałość w związku z przypadkowymi okolicznościami i doraźnymi decyzjami króla wykraczały poza utarte schematy. Kumulacja problemów zmuszała do działań niestereotypowych, a reformy - choćby najmniejsze - dodatkowo uwidaczniały oznaki kryzysu, który systematycznie narastał na różnych polach. W tym kontekście zasadne jest zwłaszcza pytanie o mechanizmy karier urzędników w obrębie maisons objętych nowymi regułami, ich trwałość i możliwości awansu w zestawieniu z poprzednimi dziesięcioleciami. Kluczowe jednak jest rozstrzygnięcie problemu: jak to się stało, że w drugiej połowie XVIII wieku modernizacja dworu była zarazem oznaką jego poważnego kryzysu?

Problemy w obrębie dworów kobiecych zaczęły się w 1767 i 1768 roku. 24 czerwca 1768 roku zmarła królowa Maria Leszczyńska, małżonka Ludwika XV. Monarchini poważnie chorowała od kilku miesięcy i pozostawała w zasadzie poza oficjalnym nurtem życia dworskiego. W realiach Francji czasów ancien régime’u śmierć królowej nie była tożsama z jakąkolwiek transformacją porządku prawnego, ale oznaczała istotną zmianę dla ludzi, którzy tworzyli jej otoczenie, wchodzili w skład domu (maison) i zapewniali codzienne funkcjonowanie królewskiej małżonki zarówno

${ }^{1}$ E. Le Roy Ladurie, J.F. Fitou (collaboration), Saint-Simon ou le système de la Cour, Paris 1998, s. 43-100.

${ }^{2}$ W.S. Magdziarz, Uwodziciele władzy. Geneza i organizacja dworu Ludwika XIV, Warszawa 2013, s. 51-78.

3 J.H. Shennan, Louis XV: Public and Private Worlds [w:] The Courts of Europe: Politics, Patronage and Royalty: 1400-1800, ed. A.G. Dickens, New York-St. Louis-San Francisco 1977, s. 305-324. 
w trakcie pełnienia oficjalnych obowiązków, jak i we wszelkich sferach pozaprotokolarnych ${ }^{4}$. Zgodnie z dotychczasowym zwyczajem obowiązującym co najmniej od XVI wieku maison królowej istniał tylko w okresie, gdy przy boku króla rezydowała jego małżonka; nie przewidywano utrzymywania dworzan i sług po jej śmierci. Tracili oni swe urzędy w momencie zgonu władczyni i jeśli chcieli wchodzić w skład domu kolejnej monarchini, musieli podjąć odpowiednie starania w chwili, gdy tworzono nową instytucję dla delfiny bądź królowej Francji. Utrata stanowisk przez grupę kilkuset osób obsługujących królową oznaczała konieczność opuszczenia przez nich Wersalu (o ile nie pełnili żadnej innej funkcji w którymś z maisons istniejących w ramach dworu królewskiego), utratę gaży, wszelkich dodatkowych profitów finansowych oraz przywilejów wynikających ze statusu commenseaux. W rezultacie w czasach ancien régime'u dominowało przeświadczenie o nietrwałym charakterze służby u boku królowej. Motywowało to jej sługi do poszukiwania urzędów w maison króla - domu, którego struktury były równie trwałe jak monarszy majestat, zapewniając stabilne zatrudnienie, stałe dochody i większy niż przy boku królowej wachlarz dodatkowych profitów.

Po śmierci Marii Leszczyńskiej Ludwik XV zdecydował się na zerwanie z tą kilkuwiekową tradycją. Król wydał deklarację, w której zapowiadał utrzymanie maison swej zmarłej małżonki i wypłacanych gaży oraz zapowiadał, że słudzy królowej wejdą w przyszłości w skład domu delfiny, przyszłej małżonki królewskiego wnuka Ludwika Augusta, księcia de Berry (od 1765 r. delfina Francji). Precedens ów monarcha tłumaczył wyłącznie swym przywiązaniem do zmarłej królowej ${ }^{5}$. W rzeczywistości deklaracja z 1768 roku była logiczną konsekwencją wcześniejszych decyzji. Już po śmierci delfiny Marii Józefy Saskiej w 1767 roku monarcha zdecydował, że jej maison nie zostanie rozwiązany, ale stanie się podstawą tworzenia domu kolejnej małżonki następcy tronu. W tym przypadku kluczowe były zapewne względy emocjonalne - Ludwik XV niezwykle cenił swą synową, jej inteligencję, wrodzony takt oraz troskę, jaką otaczała jego syna, zmarłego w grudniu 1765 roku delfina Ludwika Ferdynanda (na dworze zdawano sobie sprawę z faktu, że zaraziła się gruźlicą, osobiście opiekując się mężem). Ów gest króla wobec Marii Józefy polegający na utrzymaniu jej maison był zarazem niezbyt kosztowny. Dom delfiny był skonstruowany podobnie jak służby królowej, ale zarazem pozbawiony wielu kluczowych urzędów, między innymi wielkiego jałmużnika, oraz sporej części rady; mniejsza liczebność oznaczała w tym wypadku zminimalizowane wydatki ${ }^{6}$. Zapewne $\mathrm{z}$ tego względu

${ }^{4} \mathrm{Na}$ ten temat m.in. K. Kuras, Prywatność na dworze królowej Francji. Przykład Marii Leszczyńskiej [w:] Publiczne, prywatne, intymne w kulturze XVIII wieku, red. T. Kostkiewiczowa, Warszawa 2014, s. 219-232.

5 Bibliothèque nationale de France [dalej: BnF], Arsenal ms 5861, „Déclaration du Roi pour faire jouir les officiers de la feue Reine des priviléges des commensaux de la Maison du Roi. Donnée à Versailles le 8 septembre 1768 ".

${ }_{6}^{6}$ J.-N. Guyot, Ph.-A. Merlin, Traité des droits, fonctions, franchises, exemptions, prérogatives et privilèges annexés en France à chaque dignité, à chaque office \& et à chaque état, soit civil, soit militaire, soit ecclésiastique, Paris 1786, t. 2, s. 305-306. Stan domu delfiny w 1767 r. wraz z informacjami o uposażeniu zob. C. Stryienski, La mère des trois derniers Bourbons. Marie-Josèphe de Saxe, et la cour de Louis XV, Paris 1902, s. 402-406. 
w deklaracji wydanej 29 maja 1767 roku monarcha ogłaszał, że urzędnicy zmarłej delfiny zostają dożywotnio włączeni do grona stołowników króla i objęci analogicznymi przywilejami jak grono jego własnych sług ${ }^{7}$. Oznaczało to w praktyce nierozwiązywanie maison Marii Józefy, który miał stać się niebawem podstawą organizacji analogicznej jednostki przeznaczonej do obsługi kolejnej delfiny. Perspektywa utrzymywania tego „bezrobotnego” grona wydawała się w 1767 roku niezbyt długa. Przyszłość dynastii wymagała, by zorganizować ożenek urodzonego w 1754 roku księcia de Berry najszybciej, jak się tylko dało. W drodze negocjacji dyplomatycznych już w 1769 roku ustalono, że jego małżonką zostanie Maria Antonina, córka cesarzowej Marii Teresy ${ }^{8}$.

Rozwiązanie przyjęte w 1767 roku wydawało się dość logiczne w ówczesnej sytuacji prawnej i dynastycznej. Śmierć królowej, która nastąpiła rok później, znacznie skomplikowała owe ustalenia. Powodem było przede wszystkim wyższe i bardziej prestiżowe miejsce $\mathrm{w}$ hierarchii przypisywane członkom domu monarchini w zestawieniu z personelem delfiny. W wydanej 8 września 1768 roku deklaracji monarcha, odnosząc się szeroko do zasług urzędników swej zmarłej małżonki, decydował o przyznaniu im - podobnie jak w przypadku sług delfiny - statusu swych własnych stołowników. Do dokumentu dołączono precyzyjny spis ludzi, którym przywilej ów przysługiwał. Obejmował on cały personel królowej; wyłączeniu z grona stołowników podlegali tylko słudzy zatrudnieni w ramach zlecenia bądź wykonujący epizodyczne posługi na rzecz królewskiej małżonki (ich funkcjonowanie w ramach maison regulowały najczęściej konkretne umowy, których nie sposób było zestawić z posiadaniem szarży wynikającej z królewskiego nadania) ${ }^{9}$. Równie istotne były praktyczne implikacje królewskich decyzji związane ze wzmiankowaną hierarchią istniejącą między domami członków rodziny królewskiej. Po 1768 roku to personel królowej stawał się podstawą utworzenia domu przyszłej delfiny; pomniejszeniu ulegała za to pozycja urzędników Marii Józefy Saskiej. W rezultacie mieli oni wejść w skład kolejnego kobiecego domu przeznaczonego dla przyszłej małżonki młodszego wnuka królewskiego, urodzonego w 1755 roku Ludwika hrabiego Prowansji (przyszłego Ludwika XVIII) ${ }^{10}$.

Decyzje królewskie z 1768 roku, choć były nieuchronne w świetle precedensu mającego miejsce rok wcześniej, nie były korzystne z punktu widzenia Królestwa Francji, a zwłaszcza jego budżetu. Oznaczały konieczność utrzymywania licznego personelu, który pozostawał w większości bez konkretnych zadań i którego moment ponownego zatrudnienia był w zasadzie nieokreślony. O ile w wypadku księcia de Berry szybki ożenek był niezwykle istotny, o tyle już mariaż hrabiego Prowansji wydawał się niezbyt bliski. Zapewne z tego względu urzędnicy króla dość szybko podjęli kroki, których celem była dyskretna redukcja personelu zajmującego się

\footnotetext{
7 J.-N. Guyot, P.-A. Merlin, op. cit., t. 2, s. 306.

${ }^{8}$ É. Lever, Marie Antoinette: The Last Queen of France, Paris 2006, s. 11-20; Marie Antoinette: Writings on the Body of a Queen, ed. by D. Goodman, New York-London 2013, s. 16.

9 BnF Arsenal, ms 5861, „Déclaration du Roi [...] le 8 septembre 1768”.

${ }^{10}$ Archives nationales à Paris [dalej: AN], O 3742, „Déclaration concernant la maison de la feue Reine et celle de feue Madame La Dauphine [28 X 1768 r.]”.
} 
dotychczas obsługą królowej. Skoncentrowanie na tych strukturach wynikało ze względów pragmatycznych; maison monarchini był liczniejszy niż służby delfiny, gdyż w założeniu odzwierciedlał on konstrukcję domu samego monarchy. Małżonka następcy tronu pewnymi kategoriami sług nie dysponowała ${ }^{11}$. Wielki jałmużnik Marii Leszczyńskiej musiał liczyć się z likwidacją swego urzędu (ewentualnie znaczącą zmianą nomenklatury), ponieważ w domu delfiny najwyższym urzędnikiem duchownym był pierwszy jałmużnik. Takiej alternatywy nie było w przypadku stanowiska kanclerza oraz znacznej części urzędników rady, którzy w skład maison delfiny zwyczajowo nie wchodzili (zarazem otrzymywali oni na mocy decyzji króla z $1768 \mathrm{r}$. część wynagrodzenia) ${ }^{12}$.

Podejmowane działania nie mogły nadmiernie kontrastować z oficjalnymi deklaracjami monarchy, stąd próba zakulisowych rozmów z urzędnikami królowej inspirowanych z dużą dozą prawdopodobieństwa przez administrację monarszą. W pierwszym rzędzie zaczęto wywierać naciski na osoby odpowiedzialne za poszczególne służby, zachęcając między innymi pierwszego maître'a d'hôtel czy pierwszego koniuszego do zredukowania liczebności osób, które im podlegały. Takie działania mogły tylko częściowo zlikwidować finansowe obciążenie dla budżetu królewskiego wynikające z pozostawienia obu kobiecych domów; na dłuższą metę o wiele bardziej efektywne było niepowoływanie kolejnych osób na urzędy, których posiadacze rezygnowali z ich pełnienia bądź umierali. Zastrzegano zarazem, że w wypadku wystąpienia wakatu w maison królowej pierwszeństwo w ubieganiu się o urząd należy do sług zmarłej delfiny.

Chętnie wykorzystywano przesuwanie sług królowej na inne, najlepiej wyższe stanowiska w innych domach. Jedną z dam pałacowych Marii Leszczyńskiej, Marie-Françoise de Talleyrand hrabinę de Périgord, awansowano w ten sposób prestiżowy urząd damy honorowej młodszych córek królewskich: Wiktorii, Zofii i Ludwiki. Posiadana przez nią szarża damy pałacowej pozostała aż do 1770 roku nieobsadzona. Zapewne wynikało to z jakiejś umowy zawartej przy okazji awansu de Périgord, skoro po przybyciu do Francji Marii Antoniny jej damą pałacową mianowano córkę hrabiny, Marie-Jeanne de Talleyrand-Périgord markizę de Mailly ${ }^{13}$.

Wszystkie te działania odciążające budżet króla były najwidoczniej niewystarczające, skoro w 1770 roku, na sześć miesięcy przed przybyciem Marii Antoniny, zaprzestano wypłacania członkom starego dworu części wynagrodzenia - appointement. Były to specjalne gaże przyznawane przez króla na czas nieokreślony i przeznaczone na utrzymanie $\mathrm{w}$ Wersalu ${ }^{14}$. Przywrócenie appointement było jedną

${ }^{11}$ Służby delfiny stanowiły ok. 77\% maison królowej. W latach 1767-1771 różnica ta stanowiła istotny czynnik, ułatwiający redukcję personelu. Zob. W. S. Magdziarz, op. cit., s. 196.

${ }^{12}$ Szczegółowe informacje o zalecanej redukcji personelu królowej i związanych z tym rekompensat dla kierujących służbami można znaleźć w: AN O 3742, „Maison de la feue Reine. Décisions”.

${ }^{13}$ L. Horow ski, Die Belagerung des Thrones: Machtstrukturen und Karrieremechanismen am Hof von Frankreich 1661-1789, Stuttgart 2012, cd 2: Prosopographie, s. 212.

${ }^{14}$ Encyclopédie, ou Dictionnaire raisonné des sciences, des arts et de métiers, par une societé de gens de lettres, sous la rédaction de D. Diderot, J. D'Alembert, t. 1, Paris 1751, s. 554; J. Duindam, Vienna and Versailles: The Courts of Europe's Dynastic Rivals, 1550-1780, Cambridge 2007, s. 119. 
z pierwszych spraw organizacyjnych, które spadły na barki młodej delfiny, gdy tylko przybyła do Francji $1^{15}$.

Wydawać by się mogło, że decyzje królewskie z 1767 i 1768 roku zostały podjęte pod wpływem emocji i, będąc precedensami, nie były rozwiązaniami praktycznymi. Ich wpływ na finanse dworu był jednoznacznie negatywny, stworzyły one też pewien chaos organizacyjny. Zarazem pozostawienie składów obu maisons znacznie ułatwiło formowanie domu Marii Antoniny - „pierwszej damy Francji”16 - w momencie gdy decyzja o terminie jej przybyciu do Francji i małżeństwie z delfinem została podjęta. Być może Ludwik XV brał pod uwagę doświadczenia z przeszłości, a zwłaszcza casus Marii Leszczyńskiej, której dom tworzono w 1725 roku w pośpiechu, włączając w jego skład - pod wpływem chwilowych decydentów - osoby kontrowersyjne, a nawet damy o wątpliwej reputacji ${ }^{17}$. Gdy w 1770 roku Maria Antonina przekraczała granice Królestwa Francji, miała do dyspozycji sprawdzony sztab ludzi, którzy w zdecydowanej większości pełnili służbę przy boku zmarłej królowej. W pawilonie wybudowanym w Kehl - na granicy francusko-niemieckiej - oczekiwali na nią jej najważniejsi urzędnicy: pierwszy jałmużnik Pierre-Augustin-Bernardin de Rosset de Rocozel de Fleury, biskup Chartres, dama honorowa Anne-Claudine-Louise d'Arpajon hrabina de Noailles, szatna Amable-Gabrielle de Noailles diuszesa de Villars ${ }^{18}$, kawaler honorowy Charles-Gaspard-Michel hrabia de Saulx-Tavannes, pierwszy koniuszy René-Mans de Froulay hrabia de Tessé, cztery damy pałacowe oraz członkowie straży ${ }^{19}$. Jak już zaznaczono, wszyscy oni kontynuowali służbę wcześniej pełnili swe obowiązki przy królowej. Nie znaczy to zarazem, że nie było żadnych napięć dotyczących obsady maison. Rywalizacja między koteriami na dworze była zbyt intensywna, by obyło się bez sporów i nieoficjalnych akcji, animowanych między innymi przez grono tak zwanych pobożnych ${ }^{20}$.

Zetknięcie delfiny, posiadającej własne zdanie na temat funkcjonowania dworu i etykiety, z najbliższym otoczeniem oddziedziczonym po poprzedniczkach nie zawsze było satysfakcjonujące. Co prawda doradcy próbowali przekonać Marię Antoninę do objęcia członków maison protekcją w stylu wcześniejszych królowych, ale ona sama wybrała inny sposób zarządzania domem²1. Niektórzy ze sług Marii

${ }^{15}$ Correspondance secrète entre Marie-Thérèse et le comte de Mercy-Argenteau, avec les lettres de Marie-Thérèse et de Marie-Antoinette [dalej: Correspondance secrète], publiée par A. d'Arneth, A. Geffroy, Paris 1874, t. 1 s. 11, Mercy-Argenteau do Marii Teresy, Paryż, 15 VI 1770 r.

16 W.S. Magdziarz, op. cit., s. 195-196.

${ }^{17}$ K. Kuras, Dwór królowej Marii Leszczyńskiej. Ludzie, pieniadze i wplywy, Kraków 2018, s. 81-82.

${ }^{18}$ Campan podaje, że była to diuszesa de Cossé, ale jej nominacja pochodzi dopiero z $1771 \mathrm{r}$.; do powitania delfiny musiała więc być desygnowana diuszesa de Villars. J.-L.-H. Campan, Mémoires sur la vie privée de Marie-Antoinette, Paris 1823, t. 1, s. 49. Podobny błąd, zapewne wynikający z perspektywy lat, popełnia: G.-P. d'Adhémar, Souvenirs sur Marie-Antoinette, archiduchesse d'Autriche, reine de France, et sur la cour de Versailles, Paris 1836, t. 1, s. 86.

19 J.-L.-H. Campan, op. cit., t. 1, s. 49-50; Almanach royal, Paris 1771 [dalej: Almanach 1771], s. 146-148. Analizę domu z podziałem na dworskie stronnictwa można znaleźć w: G.-P. d'Adhémar, op. cit., t. 1 , s. $73-80$.

${ }^{20}$ Correspondance secrète, t. 1, s. 21, Mercy-Argenteau do Marii Teresy, Paryż, 14 VII 1770 r.

${ }^{21}$ Ibidem, s. 11, Mercy-Argenteau do Marii Teresy, Paryż, 15 VI 1770 r. 
Leszczyńskiej przetrwali okres dwuletniego intermedium związanego z faktycznym zawieszeniem funkcjonowania maisons królowej i delfiny, jednak ich współpraca z Marią Antoniną nie zawsze okazywała się możliwa. Klasycznym przykładem braku wzajemnego zrozumienia i kooperacji przyszłej królowej i części personelu kobiecego są losy hrabiny de Noailles, która ze względu na przywiązanie do form i konwenansów szybko zasłużyła w oczach małżonki delfina na przydomek madame l'Étiquette ${ }^{22}$. Do roli symbolu urosła w oczach dworu sprawa gorsetu (corps à baleines), który zdaniem hrabiny delfina powinna obowiązkowo nosić, by jej talia prezentowała się odpowiednio. Maria Antonina otwarcie nie zgadzała się z tą opinią i odmawiała dostosowania się do owej mody ${ }^{23}$. Mimo istniejących różnic i rozbieżności hrabina wytrwała w roli damy honorowej do 1775 roku, ale dla obu stron interakcji była to raczej konieczność. Dopiero po śmierci Ludwika XV Maria Antonina miała pewność, że na to stanowisko nie zostanie mianowana osoba jej nieprzychylna, na przykład dama popierana przez Jeanne Bécu hrabinę du Barry i chętnie zgodziła się na zmiany ${ }^{24}$. Hrabinę de Noailles zastąpiła Laure-Auguste de Fitzjames de Berwick księżna de Chimay, która awansowała tym samym ze stanowiska szatnej (pełniła swą funkcję przy królowej aż do 1792 r. $)^{25}$.

Zmiany w obrębie personelu obsługującego młodą delfinę następowały ze zróżnicowaną dynamiką. Wśród wysokich w hierarchii funkcji kobiecych najszybciej doszło do rotacji na stanowisku szatnej (dame d'atour). Co prawda nominację w 1770 roku otrzymała diuszesa de Villars, która pełniła służbę na dworze Marii Leszczyńskiej, jednak była ona damą nader wiekową (urodziła się w 1706 r., w służbie królowej pozostawała od 1727 r.). Jej śmierć w 1771 roku z punktu widzenia młodej delfiny oznaczała szansę na dokonanie istotnej zmiany w gronie swego najbliższego personelu. Okazję tę Maria Antonina starała się jak najlepiej wykorzystać. Sukces, jaki odniosła, był jednak połowiczny. Udało jej się co prawda utrącić u samego Ludwika XV kandydaturę Madame de Saint-Mégrin ${ }^{26}$ (miała ona wpływowych protektorów w gronie rodziny, stanowisko obiecał jej jeszcze zmarły delfin), ale nie była w stanie otwarcie przeciwstawić się wpływom hrabiny du Barry, zwłaszcza że musiała dodatkowo nieustannie lawirować $\mathrm{w}$ relacjach z Mesdames, ciotkami delfina ${ }^{27}$. W wyniku różnych przetasowań nową szatną została dość lubiana i ceniona przez delfinę AdélaïdeDiane-Hortense Mazarini-Mancini diuszesa de Cossé wywodząca się z wpływowej rodziny de Nivernais. Pełniła swą funkcję do 1775 roku, gdy zrezygnowała z niej, ku rozpaczy królowej, ze względu na konieczność opieki nad chorym synem ${ }^{28}$. Zastąpiła

22 J.-L.-H. Campan, op. cit., t. 1, s. 51.

${ }_{23}$ Correspondance secrète, t. 1, s. 33, Mercy-Argenteau do Marii Teresy, Compiègne, 4 VIII 1770 r.

${ }^{24}$ Ibidem, s. 53, Mercy-Argenteau do Marii Teresy, Paryż, 19 IX 1770 r.

${ }^{25} \mathrm{http} / / / \mathrm{www}$. chateauversailles-recherche-ressources.fr/jlbweb/jlbWeb?html=notdictionnaire\&r ef=92 [dostęp: 15 IV 2020 r.].

${ }^{26}$ Zapewne chodziło o Marie-Antoinette Rosalie de Pons de Roquefort diuszesę de Vauguyon (1751-1824).

${ }^{27}$ Correspondance secrète, t. 1, s. 164, Mercy-Argenteau do Marii Teresy, Paryż, 22 V 1771 r.

${ }^{28}$ Lettres de Marie-Antoinette. Recueil des lettres authentiques de la reine [dalej: Lettres de Marie-Antoinette], t. 1, publiées par M. de La Rocheterie, G. Du Fresne de Beaucourt, Paris 1895, s. 21, Maria Antonina do Marii Teresy, Wersal, 13 X 1771 r.; s. 92, eadem ad eandem, Wersal, 22 VI 1775 r. 
ją wówczas na krótko księżna de Chimay, a następnie, awansując z szarży damy pałacowej, markiza de Mailly, która cieszyła się dużą estymą królowej ${ }^{29}$.

Pewne modyfikacje nastąpiły również w gronie dam pałacowych (w latach 17681770 pojawiły się w różnych okolicznościach trzy nowe damy, co oznaczało rotację $25 \%$ składu tej części domu $)^{30}$. Dla niektórych dam zmarłej królowej rozpoczęcie służby u boku młodej delfiny było zabiegiem czysto instrumentalnym, mającym na celu zapewnienie kontroli nad procesem przekazywania urzędu w obrębie własnej rodziny. Był to z pewnością przypadek Marie-Anne-Julie hrabiny de Clermont-Tonnerre, damy pałacowej od 1757 roku. Hrabina w 1770 roku podjęła służbę przy boku delfiny, po czym już w sierpniu tego roku zadbała o to, by została ona scedowana na wnuczkę, Louise-Adélaïde-Victoire markizę de Clermont-Tonnerre ${ }^{31}$. Nie wszystkie damy decydowały się na tego typu zabieg, na przykład Louise-Félicité de Bréhan de Plélo diuszesa d'Agénois w 1768 roku zrezygnowała ze służby, a wytworzony w ten sposób wakat zapełniono dopiero dwa lata później, gdy stanowisko to przejęła Guyonne-Marguerite-Philippine-Élisabeth de Durfort wicehrabina de Choiseul-Praslin, która była damą zmarłej delfiny ${ }^{32}$. Trudno jednoznacznie rozstrzygnąć, dlaczego diuszesa pozwoliła sobie na taką nonszalancję. Tłumaczyć to można zarówno względami emocjonalnymi - była bardzo zżyta ze zmarłą królową i jej kręgiem - jak i praktycznymi - diuk d'Agénois był gubernatorem Bretanii, a zarazem wrogiem ministra Choiseula. W związku z problemami politycznymi małżonkowie musieli w latach 70. opuścić dwór ${ }^{33}$.

Wymiana składu dam pałacowych była procesem powolnym i rozciągniętym w czasie. Maria Antonina otrzymawszy określone najbliższe otoczenie, musiała się liczyć z jego stabilnością (co z punktu widzenia jej nowatorskich poglądów raczej nie było preferowane). Pewne mechanizmy regulujące obsadę personalną domu w realiach ancien régime'u były bezwzględne - do 1774 roku wszelkie decyzje dotyczące maison delfiny podejmował Ludwik XV. Za duży sukces Marii Antoniny należy więc uznać fakt, że gdy w 1771 roku przy jej boku pojawiła się nowa dama „do towarzystwa" - Madeleine-Suzanne-Adélaïde diuszesa de Luxembourg, była ona osobiście wybrana przez nią samą (od 1774 r. diuszesa była już damą pałacową). Delfina w liście do cesarzowej Marii Teresy podkreślała, że jest ona młoda i że wydaje się „dobrym dzieckiem" ${ }^{34}$. Co prawda po śmierci Ludwika XV jego następca dał małżonce pełną swobodę w dobieraniu członków dworu, ale to nie znaczy, że mogła ona działać dowolnie, nie licząc się z istniejącymi ramami formalnymi ${ }^{35}$. Na przykład w 1775 roku

${ }_{29}$ Ibidem, s. 102, Maria Antonina do Marii Teresy, Wersal, 15 IX 1775 r.; Correspondance secrète, t. 1, s. 116-117, Mercy-Argenteau do Marii Teresy, b.m., 22 III 1774 r.

${ }^{30}$ Almanach 1768, s. 140; Almanach 1771, s. 147.

${ }^{31}$ AN O 198, k. 166v.

32 Almanach 1767, s. 139.

${ }_{33}$ P. d'Estrée, A. Callet, La Duchesse d'Aiguillon (1726-1796) d'après des documents inédits, Paris 1912, s. 79; L. Horowski, op.cit, s. 185.

${ }^{34}$ Lettres de Marie-Antoinette, t. 1, s. 22, Maria Antonina do Marii Teresy, Wersal, 13 X 1771 r.;

Y. Combeau, Le comte d'Argenson (1696-1764) Ministre de Louis XV, Paris 1999, s. 106.

${ }^{35}$ Lettres de Marie-Antoinette, t. 1, s. 65, Maria Antonina do Marii Teresy, Choisy, 14 V 1765 r. 
do grona dam dokooptowano Colette-Marie-Pauline-Hortense-Bernardine de Beuvilliers de Saint-Aignan markizę de La Roche-Aymon, której stanowisko obiecał jeszcze Ludwik $\mathrm{XV}^{36}$. W tym samym roku damą pałacową została również Guyonne-Élisabeth-Joséphine de Montmorency Laval diuszesa de Luynes ${ }^{37}$. W 1780 roku stanowisko damy „nadliczbowej” objęła Thérèse-Lucy hrabina de Dillon ${ }^{38}$.

Pomimo sporych modyfikacji, do których doszło w obyczajowości dworu kobiecego i rozluźnienia etykiety, które cechowały przybycie do Wersalu Marii Antoniny ${ }^{39}$, damy pałacowe mianowane jeszcze za życia Marii Leszczyńskiej raczej wybierały trwanie przy boku delfiny, a następnie królowej, a wypadki dobrowolnych dymisji bez uwzględnienia kontekstu rodzinnego czy próby scedowania szarży na członka najbliższej familii były nieczęste. Do wyjątkowych należała sytuacja wydalenia z dworu Marie-Louise-Sophie de Faoulq hrabiny de Gramont. Doszło do tego po tym, jak dama pałacowa delfiny otwarcie sprzeciwiła się hrabinie du Barry oraz towarzyszącym jej paniom w kwestiach pierwszeństwa zasiadania w kaplicy (sprawa była na tyle kontrowersyjna, że hrabiny de Gramont nie uratowała nawet silna pozycja, którą zajmowała w koterii Choiseula ${ }^{40}$.

Do 1786 roku królowej udało się wprowadzić do grona dam pałacowych tylko sześć nowych osób; pozostałe damy służyły jeszcze w czasach Marii Leszczyńskiej. Dwie z nich - Gabrielle-Pauline hrabina d'Adhémar de Montfalcon oraz Louise-Charlotte-Henriette Philippine de Noailles diuszesa de Duras - wytrwały u boku nowej królowej do końca ancien régime'u. Casus hrabiny d'Adhémar pokazuje, jak duży rozdźwięk panował w relacjach królowej z damami „starej gwardii”; Maria Antonina wprost pokpiwała z ich wieku oraz kuriozalnego sposobu bycia. Męża hrabiny d'Adhémar poparła nawet w staraniach o ambasadę w Londynie - podobno tylko po to, by wyjeżdżając tam, zabrał z sobą żonę $e^{41}$. Równie trwałe okazały się kariery dam mianowanych z inicjatywy Marii Antoniny; na przykład wzmiankowana wyżej wicehrabina de Choiseul-Praslin zrezygnowała ze służby dopiero w 1788 roku $^{42}$.

36 Ibidem, s. 102, Maria Antonina do Marii Teresy, Wersal, 15 IX 1775 r.

37 L. Horowski, op. cit., CD 2: Prospographie, s. 228.

38 Correspondance secrète, t. 3, s. 401, Mercy-Argenteau do Marii Teresy, Paryż, 18 II 1780 r.

39 Symbolem zmian może być skandaliczne zachowanie markizy de Clermont-Tonnerre podczas jednej z uroczystości; zmęczona zbyt długim staniem markiza usiadła za pozostałymi damami i zabawiała się, ciągnąc je za spódnice. Zmiana obyczajowa oznaczała również rezygnację przez Marię Antoninę z części ceremonii, np. publicznego spożywania posiłków. J.-L.-H. Campan, Mémoires, t. 1, s. 90-91, 100-101. Sama królowa dość nonszalancko traktowała tradycyjne formy, które ją otaczały, zauważając np. że uroczystości Wielkiego Tygodnia bardziej ją przeziębiły niż wszystkie bale. Lettres de Marie-Antoinette, t. 1, s. 88, Maria Antonina do hrabiego de Rosenberg, Wersal, 17 IV 1775 r. Coraz częściej historycy argumentują, że taka strategia młodej królowej nie wynikała wyłącznie z kapryśnego charakteru i nieprzygotowania do pełnienia roli królowej, ale wiązała się z walką Marii Antoniny o niezależność i sferę prywatną. Por. Marie Antoinette: Writings on the Body of a Queen, s. 3.

${ }^{40}$ L. Horow ski, op. cit., s. 345. Hrabina de Gramont zdobyła silną pozycję po śmierci królowej; wystąpienie przeciw Madame du Barry miało być zapewne demonstracją wpływów. Zob. G.-P. d'Adhémar, op. cit., t. 1 , s. 13 .

41 J.-L.-H. Campan, op. cit., t. 1, s. 228, 265.

${ }^{42}$ Lettres de Marie-Antoinette, t. 2, s. 120, Maria Antonina do L.A. Le Tonneliera de Breteuil, b.m., 19 VII $1788 \mathrm{r}$. 
W rezultacie grono dam pałacowych otaczających małżonkę Ludwika XVI było ekipą tyleż zróżnicowaną pokoleniowo, ile trudną w codziennym, efektywnym zarządzaniu. Grono to raczej nie spełniało oczekiwań Marii Antoniny, co tylko motywowało królową do poszukiwania alternatywnych rozwiązań w kwestiach personalnych.

Stabilne było również grono pierwszych pokojowych, odziedziczone po poprzedniczce. Szczególną pozycję zajmowała w jego obrębie pierwsza pokojowa Julie-Louise Bibault de Misery (w służbie królowej od 1765 r.). Była ona typową reprezentantką swego środowiska - związana ze strukturami ancien régime'u, pobożna i bigoteryjna, nie wyobrażała sobie życia poza Wersalem. W jej relacjach z delfiną pozornie królowało umiłowanie form (podobnie jak to było z hrabiną de Noailles), ale zdaje się, że Madame Bibault de Misery przekroczyła w pewnym momencie subtelnie zakreślone granice, otwarcie organizując audiencje u królowej dla nieuprawnionych osób ${ }^{43}$. W rezultacie delfina, podążając za radami otoczenia, dość otwarcie zaczęła demonstrować swą rezerwę, a nawet antypatię względem pierwszej pokojowej (zdaje się, że uczucia te były obustronne). Taki stan utrzymywał się bardzo długo; dopiero w 1786 roku pierwszą pokojową, i to na zasadzie survivance, została zgodnie z preferencjami królowej Jeanne-Louise-Henriette de Campan, autorka bezcennych pamiętników dotyczących ostatniego kobiecego dworu ancien régime' ${ }^{44}$.

Równie stabilna była obsada drugiego stanowiska pierwszej pokojowej; należało ono do Élisabeth-Geneviève Perrin, która zaczęła służbę w 1766 roku przy Marii Leszczyńskiej ${ }^{45}$. Gdy w 1776 roku z powodu wieku zdecydowała się ona na opuszczenie służby, Maria Antonina miała okazję, by umieścić w tym gronie wierną sobie osobę. Jeszcze latem 1770 roku - a więc kilka miesięcy po przybyciu do Francji delfina uprosiła władcę, by włączył do grona pokojowych jako survivancier Marie-Madeleine de Thierry, żonę pierwszego pokojowca delfina, François-Christophe'a de Thierry'ego ${ }^{46}$. Po dymisji Madame Perrin to Thierry została pierwszą pokojową, ale po kilku miesiącach w związku ze słabym zdrowiem złożyła rezygnację. Zastąpiła ją inna pokojowa zmarłej królowej Marie-Élisabeth Nol de Thibault ${ }^{47}$. Pełniła ona swe obowiązki do rewolucji. Zadbano o to, by posiadała swą survivancier; była nią Regnier de Jarjaye ${ }^{48}$.

Zaskakująco w tym kontekście kształtowały się kariery 12 pokojowych Marii Antoniny. $\mathrm{Z}$ niedatowanego spisu pozostawionego przez zorientowaną $\mathrm{w}$ temacie

${ }^{43}$ Correspondance secrète, t. 1, s. 304, Mercy-Argenteau do Marii Teresy, Paryż, 15 V 1772 r.; J.-L.-H. Campan, op. cit., t. 1, s. 120.

${ }^{44}$ W.R. Newton, La Petite Cour: Services et serviteurs à la cour de Versailles au XVIII' siècle, Paris 2006, s. 264; J.-L.-H. Campan, op. cit., t. 1, s. 292.

${ }^{45}$ K. Kuras, Dwór królowej, s. 144.

${ }^{46}$ Correspondance secrète, t. 1, s. 35-36, Mercy-Argenteau do Marii Teresy, Compiègne, 20 VIII 1770 r.; s. 51, idem ad eandem, Paryż, 19 IX 1770 r. Ambasador Marii Teresy w tym wypadku mylił się Maria Antonina nie prosiła króla o stanowisko pierwszej pokojowej, ale pokojowej.

${ }^{47}$ Correspondance secrète, t. 2 s. 429, Mercy-Argenteau do Marii Teresy, Paryż, 28 II 1776 r.; s. 526-527, idem ad eandem, Paryż, 15 XI 1776 r.

48 J.-L.-H. Campan, op. cit., t. 1, s. 291; J.-G. Peltier, Histoire de la révolution du 10 aoust 1792, des causes qui l'ont produite, des événemens qui l'ont précédée, et des crimes qui l'ont suivie, Londres 1795 , t. 2 , s. 401. 
Madame de Campan wynika, że ich skład całkowicie zmienił się w porównaniu z czasami Marii Leszczyńskiej. Spis ten zapewne pochodzi z późnych lat 70. XVIII wieku, gdy jego autorka sama była zainteresowana sytuacją w komnacie królowej jako potencjalna kolejna pierwsza pokojowa. Skala rotacji, do jakiej doszło, nawet biorąc pod uwagę te zastrzeżenia, była zaskakująco duża - żadna z pokojowych wymienionych przez Madame de Campan nie wchodziła w skład komnaty w domu Marii Leszczyńskiej" ${ }^{49}$.

Ze względu na stabilność składu najwyższego personelu kobiecego (środowisko pokojowych było w tym zakresie wyjątkiem) Maria Antonina starała się promować nowe, przychylne sobie osoby - celem tych działań było przełamanie dominacji kręgu kojarzonego ze zmarłą królową i stronnictwem pobożnych. Nie wszyscy ludzie, którzy pojawili się w jej maison w tych okolicznościach, byli nowi na dworze. Typowym przykładem takiej kariery były losy Laure-Auguste Fitzjames księżnej de Chimay, która rozpoczęła służbę jako dama pałacowa jeszcze w 1762 roku i w 1770 roku podjęła obowiązki przy boku Marii Antoniny. Z delfiną szybko połączyła ją nić sympatii i zrozumienia - w czerwcu 1775 roku to księżna de Chimay otrzymała nominację na szatną królowej, a we wrześniu tego roku została damą honorową (pozostała na tym stanowisku aż do końca istnienia maison) ${ }^{50}$.

W związku z ograniczonymi możliwościami rotacji w obrębie personelu kobiecego Maria Antonina zdecydowała się sięgnąć po rozwiązanie alternatywne, wskrzeszając wygaszony w 1741 roku urząd nadintendentki. Maria Leszczyńska świadomie wywalczyła likwidację tej szarży, cedując związane z nią uprawnienia na inne członkinie swego domu. Maria Antonina wystarała się o ponowne powołanie nadintendentki, która formalnie była najwyższą zwierzchniczką całego personelu kobiecego, członkinią rady, posiadała też istotne uprawnienia honorowe oraz administracyjne ${ }^{51}$. Celem małżonki Ludwika XVI nie była bynajmniej reforma zarządzania maison, a raczej umożliwienie zaufanej i lubianej osobie wejście do jego struktur.

W rezultacie w 1775 roku - nieprzypadkowo w momencie gdy diuszesa de Noailles wyraziła chęć rezygnacji z szarży damy honorowej - na urząd nadintendentki została powołana faworytka królowej Marie-Thérèse de Savoie-Carignan księżna de Lamballe, która pozostała na tym stanowisku aż do 1792 roku $^{52}$. Ponowne mianowanie nadintendentki wzbudziło poważne animozje wśród niższego personelu; swe oburzenie demonstrowały otwarcie zarówno dotychczasowa dama honorowa, jak i szatna, które - skądinąd zapewne słusznie - obawiały się omnipotencji królewskiej przyjaciółki ${ }^{53}$. Pretensje zgłaszała hrabina de Gramont - w jej opinii szarża ta mo-

${ }^{49}$ K. Kuras, Dwór królowej, s. 144-145; J.-L.-H. Campan, op. cit., t. 1, s. 293-295.

${ }_{50}$ J.-L.-H. Campan, op. cit., t. 1, s. 287; Correspondance secrète, t. 2, s. 351, Mercy-Argenteau do Marii Teresy, Paryż, 23 VI 1775 r.

${ }^{51} \mathrm{~W}$ momencie wskrzeszenia szarży nadintendentki ożyły debaty dotyczące podziału kompetencji między nią a damą honorową. Zob. AN O 3742, „Madame la princesse de Chimay demande”.

52 J.-L.-H. Campan, op. cit., t. 1, s. 134-135, 285-286; Lettres de Marie-Antoinette, t. 1, s. 96-97, Maria Antonina do hrabiego de Rosenberg, 13 VII 1775 r.; S. Grant, Female Portraiture and Patronage in Marie Antoinette's Court: The Princesse de Lamballe, New York-London 2019, s. 32, 38.

${ }_{53}$ Mémoires de Mme de Genlis sur la cour, la ville et les salons de Paris, Paris 1868, s. 63; Correspondance secrète, t. 2, s. 195, Mercy-Argenteau do Marii Teresy, Paryż, 15 VII 1774 r. 
gła być wskrzeszona, o ile zostałaby przeznaczona dla niej samej ${ }^{54}$. Maria Antonina trwała przy swym wyborze; w liście do Marii Teresy tłumaczyła nawet, że jej przyjaciółka to nieskazitelna osobowość i nie ma w sobie nic z „włoskiego charakteru”, o który posądzają ją przeciwnicy (delfina znała księżnę co najmniej od $1771 \mathrm{r}$.) ${ }^{55}$. W wyniku tych sporów na nowo zdefiniowano kompetencje nadintendentki, które w porównaniu z czasami Marii Leszczyńskiej zostały znacząco pomniejszone i ograniczone do zagadnień ceremonialnych. Nadintendentka na przykład organizowała pożegnalne kolacje dla gości, których Maria Antonina chciała w szczególny sposób uhonorować. Wszelkie szczegółowe spory kompetencyjne, a tych nie brakowało między najwyższym w hierarchii personelem kobiecym, rozstrzygała królowa ${ }^{56}$.

W połowie lat 70. rozpoczęła się również błyskotliwa kariera Gabrielle-Yolande-Claude Martine hrabiny, a następnie diuszesy de Polignac (zwano ją hrabiną Jules de Polignac). Nić sympatii, jaka została nawiązana między nią a młodą królową podczas jej krótkiego pobytu na dworze, nie zaowocowała szybkim awansem. Maria Antonina zachwycona nowo poznaną towarzyszką i tym, że obecność de Polignac gwarantowała jej swobodę i dobre samopoczucie, podjęła starania, by sprowadzić ją na stałe do Wersalu ${ }^{57}$. W 1775 roku diuszesa była bliska królowej, ale zbyt młoda, by powierzyć jej szarżę damy honorowej ${ }^{58}$. W latach 1777-1781 nie doszło do jakichkolwiek zmian w składzie dam pałacowych, królowa nie miała więc szczególnych możliwości manewru, zwłaszcza że wyższe urzędy kobiece były zajęte bądź zostały już rozdysponowane zgodnie z jej preferencjami.

Diuszesa de Polignac musiała czekać na swą szansę aż do roku 1782, gdy otrzymała stanowisko guwernantki dzieci królewskich. Było to posunięcie wyjątkowo korzystne z punktu widzenia królowej, która w ten sposób nie tylko umieszczała przyjaciółkę w strukturach dworu królewskiego (oferując jej skądinąd wysokie stanowisko), ale i zyskiwała spory wpływ na edukację swego potomstwa ${ }^{59}$. Analogicznie do przypadku księżnej de Lamballe nominacja ta nie wzbudziła szczególnego entuzjazmu wśród dworzan. Nie chodziło jednak o podział kompetencji, ale o urażone ambicje wielkich rodzin, z punktu widzenia których diuszesa była trudna do zaakceptowania na stanowisku guwernantki dzieci królewskich (wcześniej urząd ten znajdował się w rękach reprezentantek pięciu generacji tej samej rodziny) ${ }^{60}$.

${ }^{54}$ G.-P. d'Adhémar, op. cit., t. 2, s. 228-229.

${ }^{55}$ Lettres de Marie-Antoinette, t. 1, s. 102, Maria Antonina do Marii Teresy, Wersal, 15 IX 1775 r.; Correspondance secrète, t. 1, s. 140, Mercy-Argenteau do Marii Teresy, Paryż, 17 III 1771 r.

${ }^{56}$ H.-L. d'Oberkirch, Wspomnienia, wstęp S. Meller, thum. E.T. Sadowska, Warszawa 1981, s. 101-102; W.R. Newton, La Petite Cour, s. 255-256.

${ }^{57}$ Mémoires du baron de Besenval, éd. Berville et Barrière, t. 1, Paris 1821, s. 333-336; H.-L. d'Oberkirch, op. cit., s. 71; P. de Nolhac, La reine Marie-Antoinette [version numérique], 2013, s. $13-15$.

${ }^{58}$ Correspondance secrète, t. 2, s. 367, Mercy-Argenteau do Marii Teresy, Paryż, 16 VIII 1775 r.

59 J.-L.-H. Campan, op. cit., t. 1, s. 138-143; W.R. Newton, La Petite Cour, s. 307-308.

${ }^{60}$ J.-L.-H. Campan, op. cit., t. 1, s. 144, 220. Królowa wybrała również następczynię diuszesy de Polignac. Została nią Louise-Élisabeth de Croÿ de Tourzel. Zob. Lettres de Marie-Antoinette, t. 2, s. 140, Maria Antonina do diuszesy de Polignac, 12 VIII 1789 r. O kolejnych guwernantkach zob. W.R. Newton, La Petite Cour, s. 304-308. 
Na miano stabilnej - a w oczach Marii Antoniny zapewne skostniałej - zasługiwała również sytuacja $\mathrm{w}$ obrębie najważniejszych urzędów sprawowanych przez mężczyzn. Małżonka Ludwika XVI odziedziczyła kawalera honorowego, pierwszego koniuszego oraz pierwszego maître d'hôtel po Leszczyńskiej i musiały upłynąć lata, by na tych stanowiskach nastąpiła zmiana. Pierwszy wyłom uczynił hrabia de Saulx-Tavannes, który już w 1771 roku wystarał się, by jego sukcesorem na zasadzie survivance został syn, Charles-François-Casimir de Saulx hrabia de Tavannes (od 1786 r. diuk de Saulx-Tavannes). Spełniał on wszelkie możliwe kryteria, by objąć tę funkcję - był wojskowym w szarży brygadiera armii królewskiej oraz gubernatorem zamku Taureau (funkcję tę sprawowali kolejni reprezentanci rodziny). Stanowiska przy boku królowej nie przejął natychmiast; dopiero gdy w 1779 roku hrabia de Saulx-Tavannes zrezygnował ze służby, jego urząd przeszedł na syna ${ }^{61}$. W praktyce dziedziczne stały się również szarże pierwszego maître d'hôtel, płynnie przekazywane w czasach Marii Leszczyńskiej i Marii Antoniny na kolejnych reprezentantów rodziny de Talaru oraz urząd pierwszego koniuszego, który w latach 1742-1789 trzymał jeden człowiek, René-Mans de Froulay hrabia de Tessé6 ${ }^{6}$. Był on ceniony przez Marię Antoninę, która wystarała się dla niego u króla o prestiżowy cordon bleu ${ }^{63}$. Od 1776 roku jego survivancier był Jules-François-Armand de Polignac, co było wynikiem interwencji samej królowej, szczególnie zainteresowanej losami lubianej rodziny. Maria Antonina przeforsowała swój wybór mimo tego, że szarża intensywnie przyciągała uwagę wpływowej rodziny de Noailles ${ }^{64}$. W opinii Pierre'a de Nolhac decyzja ta była typowa dla strategii nominacyjnej Marii Antoniny, w której dominowały jej osobiste preferencje, co w konsekwencji prowadziło do spadku popularności władczyni wśród starych i wpływowych rodzin mocno osadzonych w realiach Wersalu ${ }^{65}$.

Wstąpienie na tron Ludwika XVI umożliwiło też większą niż dotychczas rotację w obrębie personelu kaplicy. Maria Antonina, już jako królowa, miała wreszcie prawo do posiadania wielkiego jałmużnika, którym został dotychczasowy pierwszy jałmużnik Marii Leszczyńskiej, a następnie delfiny biskup de Rosset de Rocozel de Fleury. Zwolnioną w ten sposób szarżę pierwszego jałmużnika otrzymał, zgodnie z wolą nowej królowej, Louis-Hector-Honoré-Maximilien de Sabran, biskup Nancy (w 1780 r. po śmierci biskupa Chartres awansował na wielkiego jałmużnika) ${ }^{66}$.

Karierę na dworze Marii Antoniny z powodzeniem kontynuowali też członkowie służb medycznych zmarłej królowej. Nie było to grono zbyt liczne, a zarazem wysoce specjalistyczne i obdarzone licznymi honorowymi przywilejami (oraz stanowiskami w innych częściach dworu), zapewne więc nie dążono do szczególnych redukcji w jego obrębie. Funkcję pierwszego lekarza zachował aż do roku 1788 roku

${ }^{61}$ L. Horowski, op. cit., CD 2, Prospographie s. 181-182. Diuk de Saulx-Tavannes był kawalerem honorowym królowej do $1792 \mathrm{r}$.

${ }^{62}$ Obejmując szarżę, był małoletni, co wyjaśnia fakt, iż był pierwszym koniuszym kolejno królowej Marii Leszczyńskiej, a następnie delfiny i królowej Marii Antoniny.

${ }^{63}$ Lettres de Marie-Antoinette, t. 1, s. 115, Maria Antonina do Marii Teresy, Wersal, 27 II 1776 r.

${ }^{64}$ Ibidem, s. 130, Maria Antonina do Marii Teresy, 14 IX 1776 r.

${ }^{65}$ P. de Nolhac, op. cit., s. 15-16, 89.

${ }^{66}$ Lettres de Marie-Antoinette, t. 1, s. 65, Maria Antonina do Marii Teresy, Choisy, 14 V 1774 r. 
Joseph-Marie-François Lassone, mianowany jeszcze w 1758 roku Ten ceniony anatomista i znany autor traktatów medycznych w 1774 roku został mianowany survivancier pierwszego lekarza króla (królowa zdecydowała się na zachowanie go stanowisku również przy swoim boku, gdy już objął obowiązki przy królu; uważała go za autorytet $\mathrm{w}$ dziedzinie medycyny ${ }^{67}$. W tym samym roku nadzorował on szczepienie na ospę dzieci królewskich ${ }^{68}$. Również pierwszego chirurga Maria Antonina odziedziczyła po Marii Leszczyńskiej. Był to mianowany w 1765 roku Jean Chavignac, członek znanej familii z tradycjami, który służył przy boku nowej królowej co najmniej do 1789 roku ${ }^{69}$.

Spora część urzędników królowej była tytularna, jak maître garderoby czy intendent domu i finansów. Funkcje te stanowiły pewien atut w budowaniu prestiżu osoby i rodziny w realiach dworu królewskiego. Kolejne królowe interesowały się tymi urzędami raczej marginalnie, tylko epizodycznie angażując się w sprawy tych nominacji. Odmienna była sytuacja tej części męskiego personelu, która miała częsty i bezpośredni kontakt $\mathrm{z}$ władczynią, a nawet zasługiwała na miano jej zauszników bądź doradców. Co ciekawe, nie dotyczyło to spowiednika. Maria Antonina zerwała $\mathrm{z}$ tradycją poprzednich królowych i zrezygnowała ze spowiednika pochodzącego z jej ojczystego kraju; zadecydowała, że rozgrzeszenia udzielał jej będzie duchowny służący również królowi, ojciec Louis-Nicolas Maudoux ${ }^{70}$. O wiele większe wpływy posiadał za to inny duchowny z kręgu królowej, ojciec Mathieu-Jacques de Vermond, formalnie pełniący funkcję jej lektora (została ona wskrzeszona w czasach Leszczyńskiej dla François-Augustina de Paradis de Moncrifa, który zmarł w 1770 r.). Vermond był wychowawcą Marii Antoniny i mimo upływu lat zachował spory wpływ na jej decyzje. Symbolem jego pozycji była spora przestrzeń, którą zajmował i stale ulepszał w obrębie Wersalu (w Grand Commun, a nie w samym pałacu) ${ }^{71}$.

Wyjątkowe w skali maison kobiecego były losy członków rady Marii Leszczyńskiej. Pomimo królewskiej deklaracji z 1768 roku duża część tych stanowisk została zlikwidowana; wynikało to z faktu, że rada delfiny nie była tak liczna jak rada królowej. Redukcje były znaczące: na ogólną liczbę 21 członków rady królowej tylko siedem osób zachowało swe urzędy przy boku delfiny w 1770 roku. Jedyną nową personą w tym gronie był nadintendent finansów René-Jacques Le Prestre de Châteaugiron, prezydent à mortier parlamentu w Bretanii. Rada w tak okrojonej wersji funkcjonowała do 1774 roku, po czym - już w ramach domu królowej - została ponownie przekształcona w formę istniejącą w czasach Marii Leszczyńskiej. Owa transformacja nie polegała bynajmniej wyłącznie na dokooptowaniu do składu starych sług zmarłej królowej (czego można by się spodziewać zgodnie z królewską deklaracją z 1768 r.). Rekonstrukcję z 1774 roku wykorzystano w celu dokonania częściowej wymiany

${ }^{67}$ A. Lunel, La maison médicale du roi : XVI ${ }^{e}-X V I I I^{e}$ siècles, le pouvoir royal et les professions de santé, médecins, chirurgiens, apothicaires, Seyssel 2008, s. 306; Correspondance secrète, t. 3, s. 48, Mercy-Argenteau do Marii Teresy, Paryż, 16 IV 1777 r.

${ }_{68}$ J.-M.-F. Las sone, Rapport des inoculations faites dans la famille royale au château de Marli. L $\hat{u}$ à l'Académie Royale des Sciences le 20 Juillet 1774, [Paris] 1774.

${ }^{69}$ W.R. Newton, La Petite Cour, s. 463.

${ }^{70}$ Ibidem, s. 247, 476.

71 J.-L.-H. Campan, op. cit., t. 1, s. 300-301. 
składu rady; spośród 21 osób, które służyły Marii Leszczyńskiej, tylko osiem ponownie weszło w skład tej instytucji (w $1774 \mathrm{r}$. notowano jeden wakat) ${ }^{72}$.

Nie było to zjawisko szczególnie dziwne; w skład rady wchodzili w większości prawnicy rezydujący w Paryżu, dla których utrzymywanie synekury przy boku królewskim nie zawsze było opłacalne. Część członków rady szybko starała się o przekazanie urzędu, stąd dość liczne przypadki survivance. Znamienna była właściwie tylko zmiana na stanowisku kanclerza. Za Marii Leszczyńskiej urząd ten znajdował się w ręku Louisa Phélypeaux hrabiego de Saint-Florentin, po czym - po rekonstrukcji rady - przejął go markiz Antoine-René de Paulmy d'Argenson, dyplomata, polityk i znany kolekcjoner (zm. w 1787 r. $)^{73}$. Po śmierci zaś literata i historyka Charlesa-Jeana-François de Hénaulta w 1770 roku nowym nadintendentem finansów został Louis-Bénigne-François Berthier de Sauvigny ${ }^{74}$.

Wgląd w losy dworzan, którzy weszli w skład utworzonego w 1770 roku i powiększonego w 1774 roku maison Marii Antoniny, pozwala na uczynienie kilku uwag. Analiza polityki nominacyjnej króla Ludwika XV oraz biegu karier sług umożliwia odnotowanie absolutnej dominacji personelu Marii Leszczyńskiej w procesie kreowania domu nowej delfiny, a następnie królowej. Dworzanie Marii Józefy Saskiej, którzy w świetle deklaracji z 1767 roku mieli być podstawą utworzenia, a w myśl postanowień wydanych rok później uzupełnienia domu przyszłej żony delfina, zostali w praktyce pozbawieni możliwości kontynuowania kariery w obrębie najważniejszego kobiecego maison. Dotyczyło to członków kaplicy, dam pałacowych, najważniejszych reprezentantów personelu męskiego oraz rady. Spośród tego grona tylko jedna dama dworu, wicehrabina de Choiseul, od 1770 roku kontynuowała służbę przy Marii Antoninie.

Karierę przy jej boku rozpoczęli też dwaj inni słudzy delfiny Marii Józefy Saskiej. Skarbnik generalny Geoffroy Chalut de Verin jeszcze w 1767 roku wystarał się o nominację na zasadzie survivance na maître d'hôtel ordynaryjnego delfiny po swym bracie, Félixie Chalut, i objął to stanowisko w 1778 roku$^{75}$. Słudze temu bliska była typowa strategia kumulowania urzędów na dworze w celu stabilizacji pozycji i właściwego dochodu; od 1753 roku był jednym z poborców podatków królewskich i z tego względu musiał sprawnie poruszać się w kręgach zbliżonych do monarchy i jego ministrów wieku. Był nie tylko sługą dwóch kolejnych delfin, ale i radcą sekretarzem oraz lektorem króla oraz skarbnikiem Madame, Marii Józefiny Sabaudziej hrabiny Prowansji (żony młodszego brata Ludwika XVI) ${ }^{76}$.

Nieco odmienny był przebieg kariery innego ze sług Marii Józefy Saskiej, mlecznego brata Ludwika XV, Louisa Merciera de Saint-Vigor. Pełnił on co prawda urząd

${ }^{72}$ Almanach 1768, s. 140-141; Almanach 1771, s. 147-148; Almanach 1775, s. 163-164.

73 Almanach 1775, s. 163.

74 W.R. Newton, La Petite Cour, s. 250. Nadintendent finansów był bardziej znany ze swej działalności w Paryżu: G. de Berthier de Sauvigny, Bertier de Sauvigny Louis Bénigne François (17371789) [w:] „Encyclopædia Universalis”, http://www.universalis.fr/encyclopedie/louis-benigne-francois-bertier-de-sauvigny/ [dostęp: 30 III 2020 r.].

${ }^{75}$ Almanach 1779, s. 169.

${ }^{76}$ Journal de Paris, R. 1787, vol. 237, s. 1038. 
maître d'hôtel ordinaire na dworze zmarłej delfiny, ale to nie to stanowisko stało się jego przepustką do kariery w poszerzonym w 1774 roku maison Marii Antoniny. Mercier de Saint-Vigor był od 1750 roku jednym z dwóch kontrolerów generalnych maison królowej (drugim był jego rodzony brat; stanowisko to faktycznie odziedziczyli oni po ojcu $)^{77}$ i w momencie gdy dom delfiny był przekształcany w struktury obsługujące monarchinię, Mercier de Saint-Vigor wszedł w jego skład z racji funkcji pełnionej ongiś przy Marii Leszczyńskiej ${ }^{78}$. Zarówno więc w przypadku Merciera de Saint-Vigor, jak i Chalut de Vérin fakt pozostawania na służbie Marii Antoniny nie wynikał z realizacji królewskich deklaracji dotyczących personelu Marii Józefy Saskiej, ale stanowił raczej wynik połączenia ambicji i konsekwentnego realizowania określonej wizji kariery na dworze.

Analiza składu personalnego maison Marii Antoniny nie oznacza bynajmniej, że na dworze nie znalazło się miejsce dla sług zmarłej w 1767 roku delfiny. Po roku 1768 roku ich możliwości zostały znacznie ograniczone przez dominację personelu Marii Leszczyńskiej, a następnie preferencje samej Marii Antoniny, ale deklaracje królewskie dawały pewne pole manewru, które skwapliwie wykorzystywano. W 1771 roku w momencie ślubu młodszego wnuka Ludwika XV, Ludwika hrabiego Prowansji, z Marią Józefiną Sabaudzką personel Marii Józefy Saskiej stał się w szerokim zakresie podstawą utworzenia kolejnego kobiecego maison. Starzy słudzy delfiny, mimo upływu czterech lat od jej śmierci, zdominowali nowe struktury. Hrabina Prowansji odziedziczyła po Marii Józefie Saskiej większość składu kaplicy; wyjątkiem był jej pierwszy jałmużnik, którym został jeden z preceptorów odpowiedzialnych niegdyś za edukację jej męża, Claude-Charles de Monstuejouls ${ }^{79}$.

Do rewolucyjnych zmian nie doszło również w gronie służb kobiecych. Nominację na damę honorową otrzymała Louise-Diane-Françoise diuszesa de Brancas, która jednak już pod koniec grudnia 1771 roku złożyła rezygnację; zastąpiła ją dotychczasowa szatna, nowa w gronie sług hrabiny Prowansji, Marie-Christine-Chrétienne hrabina de Valentinois (pełniła swą funkcję do śmierci w 1774 r. . $^{80}$. Spośród dziewięciu dam pałacowych hrabiny aż sześć wchodziło w skład otoczenia Marii Józefy Saskiej przed 1767 rokiem. Podobnie kształtował się skład najistotniejszych urzędników męskich - niezmienna pozostała obsada na stanowiskach kawalera honorowego, pierwszego koniuszego (w tym przypadku urząd objął dotychczasowy survivancier), pierwszego maître d'hôtel, maître garderoby, dwóch sekretarzy rozkazów, intendenta maison, a także skarbnika generalnego, wzmiankowanego już wcześniej Chalut de Vérina ${ }^{81}$. Wersalska rzeczywistość okazała się zaskakująco łaskawa dla

${ }^{77}$ K. Kuras, Dwór królowej, s. 172.

${ }_{78}$ Jego służbę odnotowano ponownie dopiero w poszerzonej wersji sług królowej: Almanach 1778, s. 169

${ }^{79}$ L. Lainé, Archives généalogiques et historiques de la noblesse de France, Paris 1841, t. 7, s. 36.

${ }^{80}$ L. Horowski, op. cit., CD 2: Prosopographie, s. 353-354. Hrabina de Valentinois wchodziła w latach 1760-1771 w skład maison Madame Adelajdy, córki Ludwika XV. Nominację na szatną w maison małżonki młodszego wnuka Ludwika XV otrzymała w 1770 r. Correspondance secrète, t. 1, s. 32, Mercy-Argenteau do Marii Teresy, Compiègne, 4 VIII 1770 r.

${ }^{81}$ Almanach 1767, s. 139; Almanach 1772, s. 151. 
ludzi zmarłej delfiny - stanowiska u boku hrabiny Prowansji szybko stały się dość satysfakcjonującą rekompensatą dla starych sług Marii Józefy Saskiej, którzy nie mieli szansy, by wejść w skład maison nowej delfiny, a następnie królowej Marii Antoniny.

Deklaracje królewskie z 1767 roku i 1768 roku odnoszące się do sług delfiny Marii Józefy Saskiej oraz królowej Marii Leszczyńskiej były precedensem na tle dotychczasowej praktyki rekrutowania personelu domów kobiecych oraz nominowania ich członków. Znacznie skomplikowały one możliwości manewru, jakimi dysponowała młoda delfina, a następnie królowa Maria Antonina, gdyż stworzyły wyjątkowo szerokie grono personelu, z którym musiano się liczyć, podejmując decyzje dotyczące jej maison oraz maison hrabiny Prowansji. Do 1774 roku wszelkie kwestie związane z obsadą urzędów leżały całkowicie w gestii króla Ludwika XV (stąd możliwy silne wpływy hrabiny du Barry na dobór otoczenia Marii Antoniny). Po wstąpieniu na tron Ludwik XVI powierzył swej małżonce wszelkie kwestie personalne dotyczące jej najbliższej świty ${ }^{82}$. W praktyce jednak Maria Antonia musiała stale brać pod uwagę nie tylko ramy formalnoprawne, w których działała (sprawiały one, że możliwości rotacji personelu były ograniczone), ale i różnorodne interesy osób bądź rodzin, których głównym źródłem były wzmiankowane deklaracje królewskie.

Kroki podjęte przez Ludwika XV w odniesieniu do domów Marii Józefy Saskiej oraz Marii Leszczyńskiej były wyrazem ewolucyjnych zmian, którym podlegał dwór francuski w XVIII wieku. Reguły dotyczące postępowania ze sługami w wypadku śmierci królowej bądź delfiny były jednoznaczne - ich maison przestawał istnieć, a urzędnicy tracili posiadane stanowiska, choć zachowywali status stołowników monarchy ${ }^{83}$. Zasady te były stosowane w czasie rządów Ludwika XIV między innymi po zgonach królewskiej matki Anny Austriackiej, małżonki Marii Teresy Hiszpańskiej oraz żony wnuka Marii Adelajdy Sabaudzkiej ${ }^{84}$. Ludwik XV, zrywając z tą tradycją, postępował w zgodzie z duchem dworu, który w wielu aspektach nie przypominał już otoczenia Króla Słońce. Monarcha w XVIII wieku w o wiele większym stopniu niż w epoce wcześniejszej musiał liczyć się z interesami dworzan. O ile za Ludwika XIV dworzanie byli „uwodzicielami władzy”"85, o tyle już pod koniec rządów Ludwika $\mathrm{XV}$ to oni warunkowali istnienie i trwanie słabnącego prestiżu urzędu monarszego. W praktyce władca, nie mając możliwości podkreślenia swej iluzorycznej pozycji w inny sposób, zdawał się całkowicie na otoczenie urzędników, ich towarzystwo, opinie i rady. Musiał ich uwodzić, by system, w którym funkcjonował, mógł nadal trwać. By utrzymać dworzan przy sobie, król był zmuszony tworzyć wrażenie, że troszczy się o tych, od których uzależniona była jego monarsza pozycja. Służyły temu między innymi takie ustępstwa, jak deklaracje z 1767 i 1768 roku, które tylko pro forma były maskowane uznaniem zasług sług zmarłej delfiny i królowej. Owe tendencje modernizacyjne były więc w rzeczywistości objawami wieloaspektowego kryzysu dworu w Wersalu, który stał się zjawiskiem trwałym w drugiej połowie XVIII wieku.

\footnotetext{
${ }^{82}$ Lettres de Marie-Antoinette, t. 1, s. 65, Maria Antonina do Marii Teresy, Choisy, 14 V 1774 r.

${ }^{83}$ W.S. Magdziarz, op. cit., s. 166.

${ }^{84}$ J.-N. Guyot, Ph.-A. Merlin, op. cit., t. 2, s. 241.

${ }^{85}$ Określenie to pochodzi z książki W.S. Magdziarza, op. cit.
} 


\section{BIBLIOGRAFIA}

\section{Źródła rękopiśmienne}

Archives nationales à Paris

O 198, 3742

Bibliothèque nationale de France

Arsenal ms 5861

\section{Źródła drukowane}

Adhémar G.-P. d', Souvenirs sur Marie-Antoinette, archiduchesse d'Autriche, reine de

France, et sur la cour de Versailles, Paris 1836, t. 1.

Almanach royal, Paris 1767.

Almanach royal, Paris 1768.

Almanach royal, Paris 1771.

Almanach royal, Paris 1772.

Almanach royal, Paris 1775.

Almanach royal, Paris 1778.

Almanach royal, Paris 1779.

Campan J.-L.-H., Mémoires sur la vie privée de Marie-Antoinette, Paris 1823, t. 1.

Correspondance secrète entre Marie-Thérèse et le comte de Mercy-Argenteau, avec les lettres de Marie-Thérèse et de Marie-Antoinette, publiée par A. d'Arneth, A. Geffroy, Paris 1874 , t. $1-3$.

Encyclopédie, ou Dictionnaire raisonné des sciences, des arts et de métiers, par une societé de gens de lettres, sous la rédaction de D. Chalut de Vérina, J. D’Alembert, Paris 1751, t. 1.

Guy ot J.-N., Merlin Ph.-A., Traité des droits, fonctions, franchises, exemptions, prérogatives et privilèges annexés en France à chaque dignité, à chaque office \& et à chaque état, soit civil, soit militaire, soit ecclésiastique, Paris 1786.

Journal de Paris, R. 1787, vol. 237.

Mémoires de Mme de Genlis sur la cour, la ville et les salons de Paris, Paris 1868.

Mémoires du baron de Besenval, éd. Berville et Barrière, Paris 1821, t. 1.

Lassone J.-M.-F., Rapport des inoculations faites dans la famille royale au château de Marli. Lù à l'Académie Royale des Sciences le 20 Juillet 1774, [Paris] 1774.

Lettres de Marie-Antoinette. Recueil des lettres authentiques de la reine, publiées par M. de La Rocheterie, G. Du Fresne de Beaucourt, Paris 1895, t. 1-2.

Oberkirch H.-L. d', Wspomnienia, wstęp S. Meller, thum. E.T. Sadowska, Warszawa 1981.

Peltier J.-G., Histoire de la révolution du 10 aoust 1792, des causes qui l'ont produite, des événemens qui l'ont précédée, et des crimes qui l'ont suivie, Londres 1795, t. 2. 


\section{Opracowania}

Combeau Y., Le comte d'Argenson (1696-1764) Ministre de Louis XV, Paris 1999.

Duindam J., Vienna and Versailles: The Courts of Europe's Dynastic Rivals, 1550-1780, Cambridge 2007.

Estrée P. de, Callet A., La Duchesse d'Aiguillon (1726-1796) d'après des documents inédits, Paris 1912.

Grant S., Female Portraiture and Patronage in Marie Antoinette's Court: The Princesse de Lamballe, New York-London 2019.

Horowski L., Die Belagerung des Thrones: Machtstrukturen und Karrieremechanismen am Hof von Frankreich 1661-1789, Stuttgart 2012.

Kuras K., Dwór królowej Marii Leszczyńskiej. Ludzie, pieniądze i wpływy, Kraków 2018.

Kuras K., Prywatność na dworze królowej Francji. Przykład Marii Leszczyńskiej [w:] Publiczne, prywatne, intymne w kulturze XVIII wieku, red. T. Kostkiewiczow a, Warszawa 2014, s. 219-232.

Lainé L., Archives généalogiques et historiques de la noblesse de France, Paris 1841, t. 7.

Le Roy Ladurie E., Fitou J.F. (collaboration), Saint-Simon ou le système de la Cour, Paris 1998.

Lever É., Marie Antoinette: The Last Queen of France, Paris 2006.

Lunel A., La maison médicale du roi: XVI -XVIII ${ }^{e}$ siècles, le pouvoir royal et les professions de santé, médecins, chirurgiens, apothicaires, Seyssel 2008.

Magdziarz W.S., Uwodziciele władzy. Geneza i organizacja dworu Ludwika XIV, Warszawa 2013.

Marie Antoinette: Writings on the Body of a Queen, ed. by D. Goodman, New York-London 2013.

Newton W.R., La Petite Cour: Services et serviteurs à la cour de Versailles au XVIII siècle, Paris 2006.

Nolhac P. de, La reine Marie-Antoinette [version numérique], 2013.

Shennan J.H., Louis XV: Public and Private Worlds [w:] The Courts of Europe: Politics, Patronage and Royalty: 1400-1800, ed. by A.G. Dickens, New York-St. Louis-San Francisco 1977.

Stryienski C., La mère des trois derniers Bourbons. Marie-Josèphe de Saxe, et la cour de Louis XV, Paris 1902.

\section{Źródła internetowe}

Berthier de Sauvigny G. de, Bertier de Sauvigny Louis Bénigne François (1737-1789) [w:] „Encyclopædia Universalis”, http://www.universalis.fr/encyclopedie/louis-benigne-francois-bertier-de-sauvigny/ [dostęp: 17.06.2021 r.].

http://www.chateauversailles-recherche-ressources.fr/jlbweb/jlbWeb?html=notdictionnaire \&ref $=92$ [dostęp: $17.06 .2021 \mathrm{r}$.]. 